\title{
Business Conflict and Pesticide Risk Regulation in Costa Rica: Supporting Data on Laws and Instructive Events, 1998-2014
}

Kees Jansen 
Jansen, Kees, 2017. Business Conflict and Pesticide Risk Regulation in Costa Rica: Supporting Data on Laws and Instructive Events, 1998-2014. Wageningen, Rural Sociology. 21 pp.; 2 tab.; 54 ref.; DOI: http://dx.doi.org/10.18174/414174

A pdf version of this work will be made available as Open Access via http://edepot.wur.nl This report can also be downloaded for free at http://dx.doi.org/10.18174/414174

This work is licensed under the Creative Commons Attribution-Non Commercial 4.0 International License, http://creativecommons.org/licenses/by-nc/4.o/

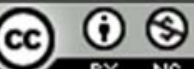

(C) 2017, Kees Jansen

\section{Rural Sociology Group}

Wageningen University

Hollandseweg 1

$6706 \mathrm{KN}$ Wageningen

The Netherlands

www.wur.nl/rso

Although all care is taken to ensure integrity and the quality of this publication and the information herein, no responsibility is assumed by the publishers, the author nor Wageningen University for any damage to the property or persons as a result of operation or use of this publication and/or the information contained herein.

\section{Acknowledgements}

This study would not have been possible without the tremendous support from IRETUNA and its faculty and staff. IRET provided a stimulating environment to carry out this research and good place for engaging discussions. My special thanks go to Douglas Barraza who has lend strong mental, intellectual, and practical support. I am grateful to Lisette Nikol for her corrections of the manuscript. 


\section{Contents}

Introduction $\quad 4$

Methodology 4

Very short history of pesticide regulation in Costa Rica 5

Short review of research in Costa Rica on pesticides 5

$\begin{array}{ll}\text { The larger field of research on pesticides } & 6\end{array}$

$\begin{array}{ll}\text { Regulatory Steps } & 7\end{array}$

By way of conclusion $\quad 16$

List with laws, regulations and verdicts $\quad 16$

$\begin{array}{ll}\text { References } & 19\end{array}$ 


\section{Introduction}

This report is a background document for Jansen (2017) and provides data on different regulatory steps in pesticide regulation in Costa Rica in the period 1998-2014. These data are deemed relevant for researching how pesticide industries have interacted with the state around the formulation of pesticide risk regulation. The report basically lists the laws and regulations that have been challenged or changed in this period. It only lists those laws and regulations that are relevant for analysing the relationships between pesticide businesses and the regulatory system. It also lists the most important judicial events such as court sentences and some media reports. Further contextualization and analysis of the data reported here has been done in Jansen (2017), which describes a business conflict between producers and traders of generic pesticides (off-patent pesticides) and research-based companies. In the early 200osafter a period of concentration, split-offs, and mergers - the "group of six" of these research-based companies consisted of Syngenta, Bayer, BASF, Monsanto, DuPont, and Dow. They controlled an estimated $75^{-80}$ percent of the agrochemical market (Dinham 2005). At the time of writing a new round of mergers was taking place. The business conflict between transnational research-based companies (hereafter TNCs) and the producers or traders of generic pesticides (hereafter Generics) followed international efforts to make pesticide registration stricter. The competing business groups contested who was allowed to make use of the risk data that a company has to provide when applying for registering a particular product. At the national level the business groups were represented by their business associations, the TNCs by the Cámara de Insumos Agropecuarios and the Generics by CANAPROGE (Cámara Nacional de Productores de Genéricos).

\section{Methodology}

For this study, I collected documents on pesticide regulation in Costa Rica between 1998-2014 and selected those that are relevant for analysing the business conflict and understanding how pesticide industries influence the formulation of regulation. Internet was a good source. Documents were downloaded from many different databases such as those of the Ministry of Agriculture, the Attorney General, and the Imprenta Nacional (with the official state newspaper La Gaceta). The Costa Rican institutions are active on the internet to make documents available, though databases are not always complete and search functions not optimal. The snowball technique was important for finding documents. Many documents refer to other documents which then could be found by specific internet searches. Some documents were supplied or referred to by interviewed informants. This report limits itself to summarizing the collected information and to providing preliminary comments in order to clarify why certain documents are relevant for elucidating the business conflict between the pesticide industries. Table 1 is structured as a timeline of different events. 


\section{Very short history of pesticide regulation in Costa Rica}

The formulation of pesticide regulation in Costa Rica strongly interacted with the development of guidelines for risk governance at the international level during the last three decades. Relevant laws were a Law on Plant Health in 1978, a law demanding that the Ministry of Agriculture would control the quality of agrochemicals in 1985, a longer decree that regulated the registration of pesticides in 1995 and a Phytosanitary Protection Law in 1998. The latter two were clearly inspired by the International Code of Conduct on the Distribution and Use of Pesticides produced by the FAO (Jansen 2008, FAO/WHO 2014, hereafter FAO-Code), whose translation into national regulation of Central American countries was supported with expertise from the FAO and development aid funding by the German development agency GTZ (GIZ since 2011) (Jansen 2003). Other international processes impacting upon the pesticide regulatory system in Costa Rica have been the Codex Alimentarius and the ongoing revalidation of pesticide registers in the USA and the EU, which determine maximum residue levels of pesticides in food. The Rotterdam Convention is another recent global impulse of regulatory improvement (Jansen and Dubois 2014). After the Phytosanitary Protection Law of 1998, a crucial next step in the evolution of the pesticide regulatory regime in Costa Rica was set by the Auditor General, who published four reports on regulatory practice in 2004 and 2005. These reports led to a state of turmoil with revisions of regulations, reorganization of involved state agencies, and political and juridical activism by pesticide industries (see Table 1 and Jansen, 2017).

\section{Short review of research in Costa Rica on pesticides}

Apart from international agreements and guidelines, other mechanisms increased the attention for pesticide risk governance as well. Not only international public interventions but also the market demanded a more judicious use and handling of pesticides, such as environmental certification in the very pesticide-intensive banana sector. Banana, a major export crop and responsible for high levels of pesticide imports in Latin America (Andreatta 1998, Barraza et al., 2011; Jansen, 2002), underwent a major greening process, whereby banana companies rationalized pest control and pesticide handling in order to be able to certify their bananas as environmentally friendly (Jansen, 2004, 2006; Murray and Raynolds, 2000). This can be explained as a response to the critique of the large amounts and damaging methods of pesticide use by banana producers. Researchers in Costa Rica have contributed extensively to the study of environmental and health effects of pesticide use (e.g. Bravo et al. 2011, 2013, Castillo et al. 2000, 2006, Polidoro et al. 2008, van Wendel de Joode et al. 1996, 2007, 2012, Wesseling et al. 1997, 2002, 2005). Also social scientists have analysed various aspects of the pesticide complex in Costa Rica (Barraza et al. 2013, Brisbois 2014, Galt 2007, 2008, 2014, García 1998, Jiménez 1995, Marquardt 2002, Thrupp 1991). Costa Rica has the highest level of pesticide use in Central America, although it re-exports an unknown percentage of the imported pesticides (Ramírez et al., 2009). Castillo et al. (1997; cited in Wesseling et al. 2005) report a use of $45 \mathrm{~kg}$ of 
active ingredients ${ }^{1}$ per hectare per year. ${ }^{2}$ The rationalization of pesticide use over the last decade did not necessarily lead to a reduction of pesticide use.

\section{The larger field of research on pesticides}

This report is part of a broader long-term research line that aims to strengthen the social analysis of pesticide risk regulation. Recently, biotechnology and nanotechnology have received much more attention from critical social scientists than the pesticide issue (e.g. Gupta 2013). Social science research has slackened. It remains unnoticed by most social scientists that a heterogeneous set of actors have worked intensively on shaping pesticide regulation over the last two decades (Cole et al. 2002, 2011, Dalvie et al. 2014, Eddleston et al. 2012, Jansen and Dubois 2014). Many practices, relationships, and narratives have changed. Although our perceptions of, and responses to, risk owe much to the pesticide issue, much has happened recently that has not yet been analysed. Important research that apparently has a social science dimension, such as the study of farmers' perceptions of risk, is not being carried out by social scientists but by agronomists or medical practitioners and is being published in science journals (e.g. Boone et al. 2014, Damalas 2015). Taking up this challenge and working in interdisciplinary teams, I have contributed to a series of collaborative studies in various countries to fill this gap (Barraza et al. 2011, 2013; Ríos-González et al. 2013; Toleubayev et al. 2007, 2010a, 2010b, 2011). Important interdisciplinary research initiatives over the last two decades have, for example, been undertaken in South Africa by researchers from the University of Cape Town (e.g. Rother 2008) and in France (Jas 2007). Examples of other interesting research include studies on the DBCP history (Bohme 2014, Rosenthal 2004), suicides (Widgers 2014), contrasting views of different environmental movements (Harrison 2011, 2014), smallholder problems (Cole et al. 2011, Stadlinger et al. 2011), regulation in developing countries (Karlsson 2000), changes in the pesticide industry (Vorley 2004) and science and expertise (Rajan 2002).

\footnotetext{
${ }^{1}$ FAO (2010: 251) defines active ingredient(s) as: "The component(s) of a formulation responsible for the direct or indirect biological activity against pests and diseases, or in regulating metabolism/growth, etc. A single active ingredient may be comprised of one or more chemical or biological entities which may differ in relative activity. A formulation may contain one or more active ingredients."

${ }^{2}$ This number has been contested. The Ministry of Agriculture has recently recalculated the data using other methods (an issue, for example, is whether you include or not pastures and re-exported products) and has reported a much lower use per hectare. However, this does not change the perspective that the use in crops like banana remains very high.
} 


\section{Regulatory Steps}

For the acronyms used in the following table, see Table 2. The number between parenthesis in in the first column refer to entries in the List with laws, regulations and verdicts. The Comments are made by the author.

\section{Table 1: Regulatory steps, 1995-2014}

\begin{tabular}{|l|}
\hline [Year] Key laws, bills and events \\
\hline [1995] Decree \#24337: Regulation of \\
the registration, use and control of \\
agricultural pesticides and auxiliary \\
substances (9)
\end{tabular}

[1998] Decree \#27532: Exempts requisites for the regulation control and use of agricultural pesticides (11)

\section{Main relevant issue; comments}

First regulation that describes more extensively the requisites for pesticide registration.

Comment: Revoked in Decree \#33495 (article 3.1); two articles (29 and 33) already revoked in Decree \#28852 [2000]

Contains little specific instructions for pesticide risk regulation but provides a more general framework within which specific regulation has to be developed.

About 84 often used pesticides are being exempted from the obligation to supply data for their registration. The state wants to 'deregulate the norm' because of the importance of pesticides for agricultural production (mentioning generic pesticides). Other argument: the Phytosanitary Service of the State (SFE) already has sufficient technical information.

Comment: This was probably the first decree supporting the Generics. It was revoked in Decree \#33495.

[2000, 4 January] Law \#7975: Law on undisclosed information

(12) [2000, 12 August] Decree \#28852: Regulation of the import of previously registered agricultural inputs and animal feed (13) [2003, 19 September] Protocol to authorize the broadening of uses of pesticides in the register

(2)

[2004 signed; ratified after the referendum of 7 October 2007] CAFTA-DR: U.S.-Central AmericaDominican Republic Free Trade Agreement (1) [2004/2005] Four reports of the Auditor General of the Republic (2-5)
Data provided for registration shall be protected against any disclosure.

Comment: This law favoured the TNCs.

This decree allows third persons to register a product that has already been registered by another person without any further requirements regarding data.

Comment: Extremely beneficial to the Generics. The TNCs start an action of unconstitutionality (see Judgement \#14295 in 2005 (29)).

Complete protocol included in DFOE-AM-19/2004 (p.61; the

Auditor General declares the protocol fully unlawful)

The protocol was issued by MAG-SFE, PROCOMER and the Cámara de Insumos Agropecuarios. Just with a simple annotation by the original registrant, the registration can be broadened to include the use of the pesticide in other crops and to change the re-entry interval and the Pre-Harvest Interval (limited to export crops). Increases the protection of firms with regard to ownership of data in the registration process. Introduces the norm of data exclusivity. Comment: This agreement favoured the TNCs and would be implemented in national regulation later on.

The Auditor General detects many problems in the registration process of pesticides and rules that new regulation has to be issued and that pesticides can only be registered upon fulfilling all requirements.

As a result, the state has to revise many processes and to issue new regulation indicating instruments to implement the existing 


\begin{tabular}{|c|c|}
\hline & $\begin{array}{l}\text { Phytosanitary Protection Law. One of the consequences is that } \\
\text { many applications for pesticide registration are being rejected, } \\
\text { mainly because of a lack of required information in the dossiers. } \\
\text { Furthermore, existing registrations have to be revalidated. }\end{array}$ \\
\hline $\begin{array}{l}\text { [2004, } 25 \text { November and } 16 \\
\text { December] News items in the } \\
\text { newspaper La Nación, which cover } \\
\text { responses to the reports of the } \\
\text { Auditor General }\end{array}$ & $\begin{array}{l}\text { The Association of Producers of the Caribbean (La Cámara de } \\
\text { Productores del Caribe), together with other organized groups (no } \\
\text { names given), request an urgent meeting with the Agricultural } \\
\text { Commission of the Legislative Assembly and the Auditor General of } \\
\text { the Republic, Âlex Solis Fallas. The producers are concerned that no } \\
\text { cheap generic pesticides will be allowed to enter the country. They } \\
\text { establish an integrated commission for all groups in order to have a } \\
\text { broad front that represents the agricultural sector of Costa Rica. }\end{array}$ \\
\hline $\begin{array}{l}{[2004,3 \text { December] Resolution }} \\
\# 13968 \text { of the Constitutional } \\
\text { Chamber of the Supreme Court } \\
\text { about the notice of appeal: } \\
\text { CANAPROGE vs Auditor General } \\
\text { and SFE } \\
(28)\end{array}$ & $\begin{array}{l}\text { The plaintiffs demand to nullify report DFOE-AM-19/2004. They } \\
\text { argue that they have not been heard during the formulation of the } \\
\text { report, which infringes their rights. The Constitutional Chamber } \\
\text { rules that the report of the Auditor General does not impose any } \\
\text { sanction on the companies of the plaintiffs, nor infringes their } \\
\text { rights. The discomfort of the plaintiffs is a normal legal issue and } \\
\text { cannot be treated with this type of appeal. The report of the } \\
\text { Auditor General does not change anything in the regulations, it } \\
\text { only demands to revise the implementation. In case of complaints } \\
\text { about a specific product registration the law grants the right to start } \\
\text { a case. Hence, the fundamental rights of the plaintiffs have not } \\
\text { been affected. }\end{array}$ \\
\hline $\begin{array}{l}\text { [2005, } 21 \text { September] Declaration of } \\
\text { the Auditor General to the } \\
\text { Constitutional Chamber \#FOE-AM- } \\
\text { o518 } \\
\text { (6) }\end{array}$ & $\begin{array}{l}\text { The Auditor General refutes the interpretations of SFE/MAG of its } \\
\text { reports, underlining that their reports do not demand the ministry } \\
\text { to act against existing regulation but precisely to implement } \\
\text { existing laws and regulations. The reports require the following: 1) } \\
\text { the state has to follow national and international norms about } \\
\text { registering a pesticide, 2) registrants have to provide the required } \\
\text { risk studies, 3) the state has to issue a technical regulation for the } \\
\text { registration of pesticides as made mandatory in the Phytosanitary } \\
\text { Protection Law, and 4) one has to discontinue illegal practices such } \\
\text { as obstructing the involvement of the Ministry of Health in decision } \\
\text { making and broadening the allowed uses of a pesticide by simply } \\
\text { making small annotations in the official decision. The Auditor } \\
\text { General declares that it never ordered to paralyse the registration } \\
\text { process but that it demands that the law has to be obeyed in the } \\
\text { registration process. }\end{array}$ \\
\hline
\end{tabular}


[2005, 19 October] Judgement \#2005-14295 of the Constitutional Chamber of the Supreme Court (29)
Action of Unconstitutionality of a group of TNCs against Decree \#28852-MAG [200o] and several articles of Decree \#28861-MAG [200o]; the latter regulates veterinary medicines. The TNCs object that third persons can register pesticides without submitting all the required data. As stated in the case file: "They consider this is, in fact, an expropriation" (Exp. oo-009436-0007-CO). The Attorney General states the opinion (in 2002) that the registration of a product does not give the registrant the rights of exclusive use or intellectual property (later also argued by the Constitutional Chamber). One cannot expect that the Ministry of Agriculture should solve conflicts about intellectual property rights. In line with previous regulations, the data in the register are being kept confidential. Hence, the action of unconstitutionality should be rejected. MAG expresses that it wants to increase competition [Comment: this is a pro-Generics argument]. The Constitutional Chamber argues that the products to be imported will be identical to the registered products, so that these are not harmful for human health or the environment. It refers to the creation of a register of 'non-registered importers'. There is no irregular deregulation. In fact, this liberalisation is conform the law on competition in defence of the consumer. The Constitutional Chamber dismisses the action of unconstitutionality.

Comment: Interestingly, the judgement was passed after publication of the reports of the Auditor General, who had already characterized Decree \#28861 as not-legal. The judgement, however, did hardly address the issue when a product is identical.
[2005, 2 November] Decree \#32873; substitutes temporarily the Head of the pesticide registration office (14)

This intervention shifts the management of the pesticide registration office at SFE-MAG from one person to a collegiate commission.

Comment: The decree followed a tumultuous, politically sensitive period after the Auditor General had published its reports. Classically, the pesticide registration office was headed by an agronomist, but in the years to come, with changing heads, people with juridical knowledge would be appointed. The co-ordinator of the collegiate commission was Sigurd Vargas Young, who would later become the lawyer defending the cases started by the Generics.

[2006, 10 May] Judgement \#62742006 of the Constitutional Chamber about the appeal of Bioquim vs SFE

(30)

Bioquim, a Generics company, argues that SFE should not base its practice on the report of the Auditor General. The Constitutional Chamber's judgement states that it is not arbitrary that the authorities of MAG demand a verification of the impact of the agrochemical.

Comment: Bioquim had started several similar cases with similar judgements by the Constitutional Chamber: see also judgement \#16361 of the Constitutional Chamber (2006, 15 November). 
[2006] The Ministry of Agriculture convenes two closed meetings with the different branches of the pesticide industry to arrive at a consensus about regulating equivalence ${ }^{3}$, the ownership of data, and temporary registration of products with incomplete risk data.

[2006, 11 August] Judgement \#11741 of the Constitutional Chamber of the Supreme Court

(31)
The first meeting in January 2006 led to more disputes (Author interviews with representatives of the Generics). The second one in June led to a signed agreement. This meeting hosted a larger group of actors with two representatives of pesticide users (farmers), the Generics, the TNCs, the Ministry of Health, the Ministry of Agriculture, and the Ministry of Environment and Energy.

The minutes, signed by all participants, deal with transitional provisions, requirements, and the handling of confidential information. The transitional provisions defined here were the same as the ones that would finally appear in Decree \#33495; only a part of the proposed Transitional Provision III would become article 7.3.2. in Decree \#33495. This article was contested later by the TNCs through an Action of unconstitutionality.

Comment: Afterwards there was disagreement about whether the signed minutes expressed a full consensus, as claimed by the Generics.

Macaya from the RIMAC company, a producer of generic pesticides, had filed an appeal to a decision of the Pesticide Registration Office to reject an application for one of the company's pesticides on the grounds that the application did not provide the toxicological information about possible effects on human health. The plaintiff argued that public agencies cannot demand more requirements than established in the law. The Chamber (referring extensively to their previous judgement \#13968 of 2004) ruled that no fundamental rights had been violated and dismissed the appeal. Comment: with this, and several similar appeals, generic producers tried to respond to rejections of their applications as a result of changes in regulation after the reports of the Auditor General. They were not successful in this legal route. provisions on the re-registration of pesticides and the temporary
[2007] Decree \#33495: Regulation for the registration, use, and control of pesticides

(16)

This detailed technical regulation specifies all the requirements (such as risk data) for the registration. It contains transitional exemptions for required documents for registration. Comment: This was the regulation that the Auditor General had asked for. This was the first regulation that required a rather complete set of risk data. However, the transitional provisions, as agreed upon in the consensus meeting, allowed temporary registration of existing applications with incomplete data. It also included a time line for the re-registration of all registered pesticides.

[2007, 4 June] Action of unconstitutionality (Constitutional Chamber): ASOPROA (some of the TNCs) vs. Decree \#33495 [resolution in 2012] (37)
Through a new organization, ASOPROA, the TNCs start an action of unconstitutionality, basically focussing on the room that Decree \#33495 offers for registering products without complete data or for registration based on equivalence without owning the data. Comment: References to the precautionary principle, FAO guidelines, sound science and environmental and health risks abound.

3 FAO (2010: 252) defines equivalence as "the determination of the similarity of the impurity and toxicological profile, as well as of the physical and chemical properties, presented by supposedly similar technical material originating from different manufacturers, in order to assess whether they present similar levels of risk". 


\begin{tabular}{|c|c|}
\hline $\begin{array}{l}\text { various news items in the media: } \\
\text { [2006] protests farmers } \\
\text { [2007] ibid. } \\
\text { [2008, March-April] }\end{array}$ & $\begin{array}{l}\text { Vocal farmer protest via the media and through meetings in } 2006 \\
\text { and 2007. Farmers demand that generic pesticides should be } \\
\text { allowed to enter the market. In March-April 2008, UPANACIONAL } \\
\text { threatens to take the streets. }\end{array}$ \\
\hline $\begin{array}{l}\text { [2008, } 19 \text { April] news item in the } \\
\text { newspaper Diario Extra }\end{array}$ & $\begin{array}{l}\text { Statement by Eduardo Robert, representative of the Cámera de } \\
\text { Insumos Agropecuarios, about the 'reservoir' of applications for } \\
\text { pesticide registration that have piled up after the reports of the } \\
\text { Auditor General in 2004. Robert asks for a stricter process. He } \\
\text { argues that eliminating this reservoir will not lead to a decline in } \\
\text { prices of agrochemicals as these are determined by international oil } \\
\text { prices. The focus of the debate should be on quality rather than } \\
\text { prices. }\end{array}$ \\
\hline $\begin{array}{l}\text { [2008, } 22 \text { April] various news items } \\
\text { on farmer protest }\end{array}$ & $\begin{array}{l}\text { UPANACIONAL street protest against restrictions on pesticide } \\
\text { registration. March of smallholders in San José; the government } \\
\text { forms a working group, including representatives of } \\
\text { UPANACIONAL, to define which pesticides are most urgently } \\
\text { needed. }\end{array}$ \\
\hline $\begin{array}{l}\text { [2008, } 23 \text { April] news item in } L a \\
\text { Nación }\end{array}$ & $\begin{array}{l}\text { MAG and protesting farmers agree to establish a committee to } \\
\text { revise and liberalize the registration of new pesticides. }\end{array}$ \\
\hline $\begin{array}{l}\text { [2008, } 27 \text { October] Decree \#34911: } \\
\text { Modification of transitional } \\
\text { provision I of Decree \#33495 } \\
(17)\end{array}$ & $\begin{array}{l}\text { Pesticides registered after } 1 \text { January } 1996 \text { can wait till after } 1 \text { January } \\
2010 \text { to present required data for registration } \\
\text { Comment: Originally these should have been presented within two } \\
\text { years after entering into force of Decree \#33495. This decree } \\
\text { changed the time frame of Decree \# } 33495 \text {. The period for re- } \\
\text { registration was being extended for some products. This decree was } \\
\text { favourable to both industry sectors. }\end{array}$ \\
\hline $\begin{array}{l}\text { [2008, } 11 \text { November] Ley \#8686: } \\
\text { Amendment of Law \#7975 } \\
(18)\end{array}$ & $\begin{array}{l}\text { "..a "new product" shall be defined as one which does not contain a } \\
\text { chemical entity that was previously approved in Costa Rica." } \\
\text { Comment: This interpretation of the definition of a new product } \\
\text { was favourable to the Generics since only new products would } \\
\text { require a full registration procedure. The same issue was being } \\
\text { discussed in Bill \#17264 in } 2008 \text { about changes in three laws; } \\
\text { leading to new regulation in } 2009 \text {. }\end{array}$ \\
\hline $\begin{array}{l}\text { [2008] Bill, project \#17124 } \\
\text { (38) }\end{array}$ & $\begin{array}{l}\text { Discussion in Congress to solve the problem that many pesticides } \\
\text { cannot be registered. Members of Congress deplore vehemently } \\
\text { that registration via equivalence is not possible and criticize that } \\
\text { the transitional provisions of Decree \# } 33495 \text { cannot be } \\
\text { implemented due to juridical limitations. They argue that generic } \\
\text { pesticides should be allowed in order to lower the price of } \\
\text { pesticides. } \\
\text { Comment: This draft law led to Law } \# 8702 \text {. The text suggested that } \\
\text { the registration of generic pesticides should be facilitated. }\end{array}$ \\
\hline
\end{tabular}


[2009, 14 January] Law \#8702:

Procedure for the applications to register agrochemicals

(21)
Law \#8702 is a temporary law with transitional provisions (Art.7 and 8), valid for a period of three years, which make registration without further data requirements possible for products or active ingredients that have been registered for more than 10 years. This law indicates that all pesticide registers have to be revalidated. Article 7 states that applications for off-patent pesticides which have been sold for more than ten years in the country do not require detailed data on physical characteristics. Article 12 protects holders of data property rights.

Comment: This law, nicknamed the 'Law of the Generics', meant to solve the so-called 'reservoir' of applications, i.e. applications that could not be processed. With reference to this law, more than 400 pesticides could be registered temporarily. The law still supported registrations (the ones registered for more than 10 years) which the Auditor General had already declared illegal. Law \#8702 also stipulated a revalidation period of maximum two or three years, depending upon when a pesticide had been registered originally. This considerably lengthened the revalidation periods (with two or three years) already stipulated in Decree \#33495 in 2007.

Nevertheless, it was first time that a law required the revalidation of all pesticide registers. Essential elements of the law were later criticized by the Attorney General (Opinion \#C-255, (8)). Specific articles in this law seemed favourable to one of pesticide businesses: Article 7 was in particular favourable to the Generics while Article 12 was favourable to the TNCs. The obligation to revalidate registrations was unfavourable to both Generics and TNCs. One interviewee also depicted it as an 'emergency law' to solve the problem of the reservoir generated by Decree \#33495.

[2009] Action of unconstitutionality: ASOPROA versus Law \#8702

(33)

[2009. 17 November] Judgement \#18171 of the Constitutional Chamber

(35)

[2009] Opinion \#C-255-2009 of the Attorney General

(8)
Action by ASOPROA [29 January 2009] against some articles of Law \#8702 that imply that the Generics in some cases are not required to provide all the information (Expedient 09-001298-0007-CO of 29 January 2009). The Constitutional Chamber rejects the action completely (Vote 2009-08917 of 27 May 2009).

Comment: The TNCs lost this case.

ASOPROA had asked MAG about the safety of products that apply for registration without toxicological and ecotoxicological studies. MAG had not yet responded after two months and ASOPROA raises an appeal about this. Two days later and 10 days before the judgement, MAG responds with a fax. The Constitutional Chamber upholds the appeal and the state has to pay for any damage. Comment: The ruling did not commented on the content of the request and the late answer by MAG.

The Ministry of Agriculture asks the Attorney General if the Health Law takes precedence over Law \#8702, as the latter "does not demand proofs of toxicology and ecotoxicology". In fact, they raise questions about the legality of specific implementations of the law. The Attorney General opinions that the Health Law takes precedence and that in case of possible health risks it is not optional, thus obligatory, to require toxicological studies. The precautionary principle has to be applied. Comment: This opinion undercut the idea of an emergency law that 


\begin{tabular}{|c|c|}
\hline & $\begin{array}{l}\text { was meant to relax the constraints for registering pesticides without } \\
\text { full documentation. }\end{array}$ \\
\hline $\begin{array}{l}\text { [2008, } 3 \text { December; enters into } \\
\text { force } 1 \text { January 2009] Decree } \\
\text { \#34903; modifies Decree \#33495 } \\
\text { (19) }\end{array}$ & $\begin{array}{l}\text { This modification dictates that registration via equivalence is only } \\
\text { allowed if property rights regarding the data used are not being } \\
\text { violated. } \\
\text { Comment: This decree was in favour of the TNCs. The Generics } \\
\text { responded with an action of unconstitutionality, which, however, } \\
\text { would be rejected by the Constitutional Chamber in the same year. } \\
\text { Partly overlapped with the later Decree \# } 35828 \text {. Remarkably, this } \\
\text { decree was launched while the action of unconstitutionality against } \\
\text { Decree \#33495 was pending. }\end{array}$ \\
\hline $\begin{array}{l}\text { [2009] Judgement \#17409 of the } \\
\text { Constitutional Chamber: Action of } \\
\text { unconstitutionality: CANAPROGE } \\
\text { versus Decree \#34903 (Exp. o9- } \\
\text { 11717-007-CO) } \\
(34)\end{array}$ & $\begin{array}{l}\text { The Generics argue that Decree \#34903 is a technical rule that has } \\
\text { been issued without following the correct procedures as established } \\
\text { by the WTO; there has not been any public consultation. The } \\
\text { Constitutional Chamber rejects the action completely (Vote } \\
2009016290 \text { of } 21 \text { October 2009) and discusses and dismisses it } \\
\text { again with Judgement \#017409 (17 November 2009).. } \\
\text { Comment: The Generics followed the same strategy as the TNCs by } \\
\text { filing an action of unconstitutionality in order to get Decree \#34903 } \\
\text { cancelled. By doing so the struggle about property rights of data } \\
\text { was moved to the arena of the Constitutional Chamber. The vote } \\
\text { was not fully clear on what grounds it rejected the action, but } \\
\text { probably it was a formal-juridical ground. }\end{array}$ \\
\hline $\begin{array}{l}\text { [2009] Minutes of the Congress, } \\
\text { Session \#54 } \\
(20)\end{array}$ & $\begin{array}{l}\text { Discussion of a motion of three members of Congress to modify } \\
\text { Law \#7975 on intellectual property and to consider an already } \\
\text { registered active ingredient as a new product. It is also proposed to } \\
\text { annul Decree \#34903. } \\
\text { One Member of Parliament, Salazar Rojas of the Partido Acción } \\
\text { Ciudadana (PAC), raises the most strident criticism of the various } \\
\text { regulations, the process, and CAFTA (the free trade agreement that } \\
\text { provides data exclusivity), which together "betray the country" and } \\
\text { are a "Christmas gift" for the TNCs. } \\
\text { Comment: The Generics seemed to get support from at least three } \\
\text { members of Congress who asked to nullify Decree \#34903, to } \\
\text { change the law on intellectual property (\#7975), and to not consider } \\
\text { an already registered active ingredient as a new product. }\end{array}$ \\
\hline $\begin{array}{l}\text { [2009, } 19 \text { August] Bill, project } \\
\# 17264 \\
(22)\end{array}$ & $\begin{array}{l}\text { The topic of this bill is the reformulation of three different articles } \\
\text { in three laws. The Permanent Commission for Agricultural Issues } \\
\text { (Comisión Permanente de Asuntos Agropecuarios) advises in line } \\
\text { with the suggestion of the Ministry of Agriculture to delete a } \\
\text { proposed reformulation of Art.8 of Law \#7975. The Generics } \\
\text { (CANAPROGE) had already protested against the reformulation as } \\
\text { it provides a definition of a new product that they contest. Instead } \\
\text { they propose the following definition: ".... a pharmaceutical or } \\
\text { agrochemical product is new, when it does not contain a chemical } \\
\text { ingredient that has been registered previously in Costa Rica, .." } \\
\text { Comment: Despite Law \#8686 this issue of the definition of "new } \\
\text { product' was still being discussed. It appeared to be a very } \\
\text { important issue for the Generics as they kept trying to redefine the } \\
\text { term 'new product'. }\end{array}$ \\
\hline
\end{tabular}




\begin{tabular}{|c|c|}
\hline $\begin{array}{l}\text { [2010, } 19 \text { February] Directive \#DM- } \\
\text { o97-10 of the Minister of } \\
\text { Agriculture } \\
(23)\end{array}$ & $\begin{array}{l}\text { This directive responds to concerns resulting from the 10 year data } \\
\text { protection as stated in CAFTA and the definition of new product } \\
\text { therein (Art.15.10). Decree \#34903 had limited the broad definition } \\
\text { of Law \#7975 (Ley de información no divulgada) to a more narrow } \\
\text { definition of only the active ingredient-technical grade. This } \\
\text { directive rules that the broader definition of new product should be } \\
\text { used, which refers to any product that contains a chemical that has } \\
\text { not been previously approved in Costa Rica. } \\
\text { Comment: This would mean that already registered formulated } \\
\text { products }{ }^{4} \text { as well as new formulations based on already registered } \\
\text { active ingredients are not new products and that risk data about } \\
\text { those products (or its active ingredients) are not protected by the } \\
\text { data exclusivity article of CAFTA. This Directive was in favour of the } \\
\text { Generics }\end{array}$ \\
\hline $\begin{array}{l}\text { [2010, } 25 \text { February] Decree \#35828; } \\
\text { nullifies Decree \#34903 and puts } \\
\text { \#33495 back in place but modifies it } \\
\text { (partly by incorporating some IPR } \\
\text { issues of Decree \#34903) } \\
\text { (24) }\end{array}$ & $\begin{array}{l}\text { This decree emphasizes the protection of data and the prohibition } \\
\text { to use protected data for the registration of products of non- } \\
\text { authorized users. Equivalence is possible if the designated authority } \\
\text { has a reference profile. Such a reference profile can only contain } \\
\text { data of proof of which the property rights have expired. } \\
\text { Comment: This decree reads as a detailed implementation of } \\
\text { CAFTA, which implied a strong support for the TNCs. The details of } \\
\text { the explanation and the repetitions at different places suggests that } \\
\text { the TNCs have influenced it (though I have no conclusive evidence } \\
\text { for this hypothesis). So, with some revisions, Decree \#33495 was } \\
\text { again the leading regulation, but now made more acceptable to the } \\
\text { TNCs (at this time the Constitutional Chamber still had to decide } \\
\text { on the action of unconstitutionality against Decree \#33495 raised by } \\
\text { the TNCs). }\end{array}$ \\
\hline $\begin{array}{l}\text { [2010, } 19 \text { March] Judgement \#05349 } \\
\text { of the Constitutional Chamber } \\
\text { (36) }\end{array}$ & $\begin{array}{l}\text { The Generics, through their lawyer Sigurd Vargas Yong, lodge an } \\
\text { appeal against MAG, demanding to nullify Decree \#34903 and re- } \\
\text { install Decree \#33495 [25 February 2010]. They argue that Decree } \\
\text { \#34903 was issued without following the right procedures, such as } \\
\text { proper consultation. Therefore their constitutional rights have been } \\
\text { violated. Furthermore, the decree has negative effects as the } \\
\text { definition of what is a 'new product' is incorrect. They argue that } \\
\text { also the Minister of Agriculture in a directive (\#DM-097-10 of 19 } \\
\text { February 2010) had stated that the definition of Law \#7975 (after } \\
\text { having been modified by \#8686) should be used. [Comment: the } \\
\text { definition in \#8686 favoured the Generics]. } \\
\text { The definition of 'new product' in Decree \#34903 only counts for } \\
\text { the active ingredient (technical grade) and not for the formulated } \\
\text { products. Formulated products will therefore fall under the rule of } \\
\text { 10 year data protection. This is contested by the Generics. } \\
\text { The appeal is disallowed because the issue as raised does not violate } \\
\text { constitutional rights and does not belong to the jurisdiction of the } \\
\text { Constitutional Chamber. } \\
\text { Comment: The Constitutional Chamber referred to her previous }\end{array}$ \\
\hline
\end{tabular}

4 FAO (2010: 253) defines a formulated product, i.e. a formulation as: "A pesticide preparation containing technical grade active ingredient(s) and formulant(s) in a form suitable for use." A formulant is: "Any substance, other than a technical grade active ingredient, intentionally incorporated in a formulation." 


\begin{tabular}{|c|c|}
\hline & $\begin{array}{l}\text { judgement (\#17409 of 2009). The question could be raised why the } \\
\text { Generics lodged a rather similar appeal. Probably they considered } \\
\text { that the directive of the Minister of Agriculture issued a few weeks } \\
\text { earlier could make a difference. }\end{array}$ \\
\hline $\begin{array}{l}\text { [2010, } 7 \text { June] Decree \#36190; } \\
\text { another modification of Decree } \\
\text { \#33495 } \\
(25)\end{array}$ & $\begin{array}{l}\text { This decree determines the documents required for the registration } \\
\text { of formulants (a substance, other than a technical grade active } \\
\text { ingredient, intentionally incorporated in a formulation), such as } \\
\text { diluents, and products like plant growth regulators or pheromones. } \\
\text { Comment: This decree would also make risk data of formulants } \\
\text { subject to a controversy regarding intellectual property rights } \\
\text { between Generics and TNCs. Similar to the controversy around } \\
\text { active ingredients. }\end{array}$ \\
\hline $\begin{array}{l}\text { [2012, } 17 \text { August] Decree \#37136; } \\
\text { this is one of several modifications } \\
\text { of \#33495 } \\
\text { (26) }\end{array}$ & $\begin{array}{l}\text { This decree basically modifies the articles in Decree } \# 33495 \text { that } \\
\text { deal with the time line of the suspension and cancelation of } \\
\text { pesticide registers and it adds an expiry date of ten years to those } \\
\text { registers that did not have one. } \\
\text { Comment: It follows from Consideration to that this decree was } \\
\text { formulated to have guidelines for what to do when registration } \\
\text { holders do not present the documents for revalidation. This relaxes } \\
\text { regulation and is beneficial to both business sectors. }\end{array}$ \\
\hline $\begin{array}{l}\text { [2012, 17 August] Resolution } \\
\text { \#2011016937 of the Constitutional } \\
\text { Chamber regarding the Action of } \\
\text { unconstitutionality by ASOPROA } \\
\text { versus Decree \#33495 (started in } \\
\text { 2007) (37) }\end{array}$ & $\begin{array}{l}\text { ASOPROA's complaint is partially accepted and an equivalence } \\
\text { procedure based on reference to another registration based on } \\
\text { incomplete data is not allowed. } \\
\text { Comment: By the time of this resolution, this issue had already been } \\
\text { regulated in the modifications of Decree \#33495. }\end{array}$ \\
\hline $\begin{array}{l}\text { [2013] Several news items in } \\
\text { national newspapers }\end{array}$ & $\begin{array}{l}\text { The Minister of Agriculture promises the pesticide industry and } \\
\text { agricultural producers that Decree \#33495 will be reformed. A main } \\
\text { theme is 'registration by incorporation', i.e. registering a pesticide } \\
\text { based on registration elsewhere, e.g. the USA or the EU, rather than } \\
\text { doing a full evaluation of all data. } \\
\text { Comment: Both Generics and TNCs seemed to support this; in any } \\
\text { case the TNCs pronounced as such in the media. }\end{array}$ \\
\hline $\begin{array}{l}\text { [2014] A bill to reform Decree } \\
\text { \#33495 is announced to will } \\
\text { become available for public } \\
\text { consultation } \\
(27)\end{array}$ & $\begin{array}{l}\text { Among other things, it introduces the possibility to register by } \\
\text { incorporation, that is, to register an active ingredient when the } \\
\text { regulation and integral evaluation of other countries (restricted to } \\
\text { the USA and the EU) guarantee a similar or higher protection level } \\
\text { than the Costa Rican norm. } \\
\text { Comment: TNCs and Generics have an interest in this bill: it gives } \\
\text { the Generics hope to be able to register products for which they do } \\
\text { not have risk data, and it gives the TNCs the option to register } \\
\text { products without releasing their proprietary data to the Costa Rican } \\
\text { government. Further analysis of the final law and implementation } \\
\text { will be needed to verify what will be the outcome. It will be } \\
\text { interesting to see what will happen if regulation in the USA and the } \\
\text { EU differs with regard to a particular product. }\end{array}$ \\
\hline
\end{tabular}




\section{By way of conclusion}

A first analysis of these data can be found in Jansen (2017). Suffice here to say that a large number of court cases, bills, laws, regulations, juridical advice, and news items have appeared that connect to the history of the business conflict between the Generics and the TNCs. Risk regulation turns out to be a contested issue and the different meanings can only be understood through careful description or 'technography' (Jansen and Vellema 2011) of many actions, practices, and narratives involved.

Table 2. Acronyms

\begin{tabular}{|l|l|}
\hline ASOPROA & $\begin{array}{l}\text { Asociación para la Protección Agropecuaria (Crop Protection } \\
\text { Association) }\end{array}$ \\
\hline CANAPROGE & Cámara Nacional de Productores de Genéricos \\
\hline FAO & Food and Agriculture Organization of the United Nations \\
\hline MAG & Ministerio de Agricultura y Ganadería (Ministry of Agriculture) \\
\hline SFE & Servicio Fitosanitario del Estado (Phytosanitary Service of the State) \\
\hline TNCs & $\begin{array}{l}\text { Transnational Companies: in the context of this study this are the larger } \\
\text { research-based pesticide producers }\end{array}$ \\
\hline UPANACIONAL & $\begin{array}{l}\text { Unión Nacional de Pequeños y Medianos Agricultores Costarricenses } \\
\text { (National Union of Small and Medium Size Farmers in Costa Rica) }\end{array}$ \\
\hline
\end{tabular}

\section{List with laws, regulations and verdicts}

This list shows the titles of the various documents. In the few cases that the document did not have a clear title, a title was provided by the author (or a short description in Spanish was added between square brackets). Dates are mentioned as day/month/year. Most documents can be downloaded from internet from different sites by including the indicated file numbers in a search string. In case of problems with finding a document you may want to contact the author of this report.

1. CAFTA-DR (2004) 'CAFTA-DR (Dominican Republic-Central America Free Trade Agreement)'.

2. Costa Rica (Contraloría General de la República) (2004) 'Informe DFOE-AM-19/2004: Informe sobre la evaluación de la gestión del estado en relación con el control de plaguicidas agrícolas'. San José.

3. Costa Rica (Contraloría General de la República) (2004) 'Informe DFOE-AM-20/2004: Informe sobre la evaluación del control interno en el proceso de registro de plaguicidas agrícolas que realiza el Servicio Fitosanitario del Estado'. San José.

4. Costa Rica (Contraloría General de la República) (2004) 'Informe DFOE-AM-50/2004: Informe relativo a los procedimientos utilizados por el servicio fitosanitario del estado para fiscalizar la calidad de los plaguicidas y sus residuos en vegetales'. San José.

5. Costa Rica (Contraloría General de la República) (2005) 'Informe DFOE-AM-51/2005: Informe sobre la función del estado en el control de los impactos de plaguicidas agrícolas en la salud humana y el ambiente'. San José.

6. Costa Rica (Contraloría General de la República) (2005) 'Informe \#FOE-AM-0518 (Oficio 11604, 21/09/2005), [Declaración de la Contraloría General a la Sala Constitucional]'. San José. 
7. Costa Rica (Procuraduría General de la República ) (2007) 'Recomendación a la Sala Constitucional, (Exp. \#o7007623 -0007-CO, 03/08/2007), [Sobre la Acción de Inconstitucionalidad de ASOPROA contra Decreto \#33495]'. San José.

8. Costa Rica (Procuraduría General de la República) (2009) 'Dictamen \#C-255-2009 [Criterio sobre Ley \#8702]'. San José.

9. Costa Rica (República de Costa Rica) (1995) 'Decreto \#24337-MAG-S (Reglamento sobre registro, uso y control de plaguicidas agrícolas y coadyuvantes)', La Gaceta, 115(16/06/1995).

10. Costa Rica (República de Costa Rica) (1998) 'Ley \#7664, Ley de Protección Fitosanitaria'. San José.

11. Costa Rica (República de Costa Rica) (1998) 'Decreto \#27532-MAG del 15/12/1998 [Exonera requisitos de Reglamento Control y Uso Plaguicidas Agrícolas]', La Gaceta, 6(11/o1/1999).

12. Costa Rica (República de Costa Rica) (2000) 'Ley \#7975, Ley de información no divulgada (o4/o1/2000) [Reformado por el artículo 6 de la Ley \#8686 del 21/11/2008]'. San José.

13. Costa Rica (República de Costa Rica) (2000) 'Decreto \#28852-MAG del 12/o8/200o: Reglamento para la Importación de Insumos Agropecuarios y Alimentos para Animales Previamente Registrados'. San José.

14. Costa Rica (República de Costa Rica) (2005) 'Decreto \#32873: Sustitución Temporal del Titular de la Gerencia de Insumos Agrícolas del Servicio Fitosanitario del Estado'. San José.

15. Costa Rica (República de Costa Rica) (2006) 'Acta de la Sesión Ordinaria \#36, Asamblea Legislativa de la República de Costa Rica, (o1/11/2006) [Discusión sobre genéricos]'. San José.

16. Costa Rica (República de Costa Rica) (2007) 'Decreto \#33495 MAG-S-MINAE-MEIC: Reglamento sobre Registro, Uso y Control de Plaguicidas Sintéticos Formulados, Ingrediente Activo Grado Técnico, Coadyuvantes y Sustancias Afines de Uso Agrícola', La Gaceta, 129(7; 10/o1/2007).

17. Costa Rica (República de Costa Rica) (2008) 'Decreto \#34911-MAG-S-MINAET-MEIC, Modificación del Transitorio I del Decreto \#33495 (27/10/2008)'. San José.

18. Costa Rica (República de Costa Rica) (2008) 'Ley \#8686: Reforma, adición y derogación de varias normas que regulan materias relacionadas con propiedad intelectual', La Gaceta, 229(26/11/2008).

19. Costa Rica (República de Costa Rica) (2008) 'Decreto \#34903 MAG-S-MINAET-MEIC-COMEX: Modificaciones al Reglamento sobre Registro, Uso y Control de Plaguicidas [Modificaciones al Decreto \#33459]', La Gaceta, 234(3/12/2008): 4-6.

20. Costa Rica (República de Costa Rica) (2009) 'Acta de la Sesión Ordinaria \#54, Asamblea Legislativa de la República de Costa Rica (16/12/2009) [Discusión sobre Proyecto \#17264, la definición de producto nuevo y las consecuencias de CAFTA]'. San José.

21. Costa Rica (República de Costa Rica) (2009) 'Ley \#8702: Trámite de las solicitudes de registro de agroquímicos [14/o1/2009]', La Gaceta, 19(28-01-2009).

22. Costa Rica (República de Costa Rica) (2009) 'Proyecto \#17264 del 27/o8/2009 [Sobre el derecho de autor]', La Gaceta, 173(4/08/2009).

23. Costa Rica (República de Costa Rica) (2010) 'Acta de la Sesión Plenaria \#135, Asamblea Legislativa de la República de Costa Rica (1/03/2010) [incluye Directriz \#DM-097-10 del Ministerio de Agricultura]'. San José.

24. Costa Rica (República de Costa Rica) (2010) 'Decreto \#35828-MAG-S-MIAET-MEIC-COMEX: La derogación, adición y modificaciones de determinadas disposiciones relativas al "Reglamento"', La Gaceta, 51(15/03/2010): 8-12.

25. Costa Rica (República de Costa Rica) (2010) 'Decreto \#3619o MAG-S-MINAET-MEIC-COMEX del o7/o6/2010 [Sobre el registro de coadyuvantes y sustancias afines; Modificación al Decreto \#33495]'. San José.

26. Costa Rica (República de Costa Rica) (2012) 'Decreto \#37136-MAG-COMEX-MINAET-S-MEIC (Modificaciones al Decreto \#33495)', La Gaceta, 134(118 (19/06/2012)). 
27. Costa Rica (República de Costa Rica) (2014) 'Texto en Consulta Nacional: Modificaciones al Decreto Ejecutivo \#33495-MAG-S-MINAE-MEIC'. San José.

28. Costa Rica (Sala Constitucional de la Corte Suprema de Justicia) (2004) 'Sentencia \#13968 Sala Constitucional de la Corte Suprema de Justicia, 03/12/2004 [Recurso de amparo CANAPROGE vs Contraloría \& SFE]', in Sala Constitucional de la Corte Suprema de Justicia (ed). San José.

29. Costa Rica (Sala Constitucional de la Corte Suprema de Justicia) (2005) 'Sentencia \#2005-14295 de la Sala Constitucional 19/10/2005 (Acción de inconstitucionalidad, FMC c.s. vs Decreto \#28852-MAG, Exp. oo009436-0007-CO), [Sobre registrar un producto por terceros sin datos propios]'. San José.

30. Costa Rica (Sala Constitucional de la Corte Suprema de Justicia) (2006) 'Sentencia \#06274 (Exp. 06-003645-007$\mathrm{CO}, 10 / 05 / 2006$, Bioquim vs. SFE), [Contestando el rechazo de solicitudes de inscripción de unos productos de Bioquim]'. San José.

31. Costa Rica (Sala Constitucional de la Corte Suprema de Justicia) (2006) 'Sentencia \#11741 de la Sala Constitucional (Macaya vs Jefe del Registro de Agroquímicos del MAG; Exp. o6-o03740-0oo7-CO, 11/o8/2006)'. San José.

32. Costa Rica (Sala Constitucional de la Corte Suprema de Justicia) (2006) 'Sentencia \#16361 (Bioquim vs. SFE, 15/11/2016), [Sobre el rechazo de la solicitud de registrar su producto a base de metalaxyl]'. San José.

33. Costa Rica (Sala Constitucional de la Corte Suprema de Justicia) (2009) 'Sentencia \#o8917 de la Sala Constitucional (ASOPROA vs Ley \#8702; Exp. 09-001298-0007-CO; 27/05/2009)'. San José.

34. Costa Rica (Sala Constitucional de la Corte Suprema de Justicia) (2009) 'Sentencia \#17409 de la Sala Constitucional (Acción de Inconstitucionalidad Macaya \& CANAPROGE vs Decreto \#34903; 17/11/2009; Exp. 09-002084-0007-CO) [Relacionado al Voto \#2009-01629o de 21/10/2009]'. San José.

35. Costa Rica (Sala Constitucional de la Corte Suprema de Justicia) (2009) 'Sentencia \#18171 de la Sala Constitucional (ASOPROA vs. MAG, Exp. 09-016369-00o7-CO, 27/11/2009), [Sobre no haber recibido respuesta a su gestión]'. San José.

36. Costa Rica (Sala Constitucional de la Corte Suprema de Justicia) (2010) 'Sentencia \#05349 de la Sala Constitucional, 19/03/2010 (Recurso de amparo Vargas Yong vs MAG c.s.), [Sobre Decreto \#34903]'. San José.

37. Costa Rica (Sala Constitucional de la Corte Suprema de Justicia) (2012) 'Resolución \#2011016937 (ASOPROA vs Decreto \#33495; 17/o8/2012), [Sobre equivalencia]'. San José.

38. Gutiérrez Gómez, C. M. (2008) 'Proyecto Ley \#17124: Ley para el trámite de las solicitudes de registro de agroquímicos [Proyecto discutido el 18/o8/2008 y el 18/12/2008]', La Gaceta, 237. 


\section{References}

Andreatta, S. L. (1998) 'Agrochemical Exposure and Farmworker Health in the Caribbean: A Local/Global Perspective', Human Organization, 57(3): 350-358.

Barraza, D., Jansen, K., van Wendel de Joode, B. and Wesseling, C. (2011) 'Pesticide Use in Banana and Plantain Production and Risk Perception Among Local Actors in Talamanca, Costa Rica', Environmental Research, 111(5): 708-717.

Barraza, D., Jansen, K., van Wendel de Joode, B. and Wesseling, C. (2013) 'Social Movements and Risk Perception: Unions, Churches, Pesticides and Bananas in Costa Rica', International Journal of Occupational and Environmental Health, 19(1): 11-21.

Bohme, S. R. (2014) Toxic Injustice: A Transnational History of Exposure and Struggle, Oakland: University of California Press.

Boone, M. D., Bishop, C. A., Boswell, L. A., Brodman, R. D., Burger, J., Davidson, C., Gochfeld, M., Hoverman, J. T., Neuman-Lee, L. A., Relyea, R. A., Rohr, J. R., Salice, C., Semlitsch, R. D., Sparling, D. and Weir, S. (2014) 'Pesticide Regulation amid the Influence of Industry', BioScience, 64(10): 917-922.

Bravo Durán, V., de la Cruz Malavassi, E., Herrera Ledezma, G. and Ramírez Muñoz, F. (2013) 'Uso de plaguicidas en cultivos agrícolas como herramienta para el monitoreo de peligros en salud', Uniciencia, 27(1):351-376.

Bravo, V., Rodríguez, T., van Wendel de Joode, B., Canto, N., Calderón, G. R., Turcios, M., Menéndez, L. A., Mejía, W., Tatis, A., Abrego, F. Z., de la Cruz, E. and Wesseling, C. (2011) 'Monitoring Pesticide Use and Associated Health Hazards in Central America', International Journal of Occupational and Environmental Health, 17(3): 258-269.

Castillo, L. E., Martínez, E., Ruepert, C., Savage, C., Gilek, M., Pinnock, M. and Solis, E. (2006) 'Water Quality and Macroinvertebrate Community Response Following Pesticide Applications in a Banana Plantation, Limon, Costa Rica', Science of the Total Environment, 367(1): 418-432.

Castillo, L. E., Ruepert, C. and Solis, E. (200o) 'Pesticide Residues in the Aquatic Environment of Banana Plantation Areas in the North Atlantic Zone of Costa Rica', Environmental Toxicology and Chemistry, 19(8): 1942-1950.

Cole, D., Orozco T, F., Pradel, W., Suquillo, J., Mera, X., Chacon, A., Prain, G., Wanigaratne, S. and Leah, J. (2011) 'An Agriculture and Health Inter-sectorial Research Process to Reduce Hazardous Pesticide Health Impacts Among Smallholder Farmers in the Andes', BMC International Health and Human Rights, 11(Suppl 2): S6.

Cole, D. C., Sherwood, S., Crissman, C., Barrera, V. and Espinosa, P. (2002) 'Pesticides and Health in Highland Ecuadorian Potato Production: Assessing Impacts and Developing Responses', International Journal of Occupational and Environmental Health, 8(3): 182-190.

Dalvie, M. A., Rother, H.-A. and London, L. (2014) 'Chemical Hazard Communication Comprehensibility in South Africa: Safety Implications for the Adoption of the Globally Harmonised System of Classification and Labelling of Chemicals', Safety Science, 61: 51-58.

Damalas, C. A. (2015) 'Pesticide Drift: Seeking Reliable Environmental Indicators of Exposure Assessment', in Armon, R. H. and Hänninen, O. (eds) Environmental Indicators, pp. 251-261. Dordrecht, Springer.

Eddleston, M., Adhikari, S., Egodage, S., Ranganath, H., Mohamed, F., Manuweera, G., Azher, S., Jayamanne, S., Juzczak, E. and Sheriff, M. R. (2012) 'Effects of a Provincial Ban of Two Toxic Organophosphorus Insecticides on Pesticide Poisoning Hospital Admissions', Clinical Toxicology, 50(3): 202-209.

FAO/WHO (Food and Agriculture Organization of the United Nations/World Health Organization) (2010) 'Manual on Development and Use of FAO and WHO Specifications for Pesticides (2nd revision)'. Rome, FAO/WHO Joint Meeting on Pesticide Specifications (JMPS).

FAO/WHO (Food and Agriculture Organization of the United Nations/World Health Organization) (2014) The International Code of Conduct on Pesticide Management (Fourth Version, Approved by the 38th FAO Conference in June 2013), Rome: FAO. 
Galt, R. E. (2007) 'Regulatory Risk and Farmers' Caution with Pesticides in Costa Rica', Transactions of the Institute of British Geographers, 32(3): 377-394.

Galt, R. E. (2008) 'Pesticides in Export and Domestic Agriculture: Reconsidering Market Orientation and Pesticide Use in Costa Rica', Geoforum, 39(3): 1378-1392.

Galt, R. E. (2014) Food Systems in an Unequal World: Pesticides, Vegetables, and Agrarian Capitalism in Costa Rica, Tucson: The University of Arizona Press.

García, J. E. (1998) 'Intoxicaciones agudas con plaguicidas: costos humanos y económicos', Pan American Journal of Public Health, 4(6).

Gupta, A. (2013) 'Biotechnology and Biosafety', in Falkner, R. (ed) The Handbook of Global Climate and Environment Policy, pp. 89-106. Oxford, John Wiley \& Sons.

Harrison, J. L. (2011) Pesticide Drift and the Pursuit of Environmental Justice, Cambridge MA: MIT Press.

Harrison, J. L. (2014) 'Neoliberal Environmental Justice: Mainstream Ideas of Justice in Political Conflict over Agricultural Pesticides in the United States', Environmental Politics, 23(4): 650-669.

Jansen, K. (2002) 'Plaguicidas y su regulación en Honduras', Ceiba, 43(2): 273-289.

Jansen, K. (2003) 'Crisis Discourses and Technology Regulation in a Weak State: Responses to a Pesticide Disaster in Honduras', Development and Change, 34(1): 45-66.

Jansen, K. (2004) 'Greening Bananas and Institutionalizing Environmentalism: Self-regulation by Fruit Corporations', in Jansen, K. and Vellema, S. (eds) Agribusiness and Society: Corporate Responses to Environmentalism, Market Opportunities and Public Regulation, pp. 145-175. London, Zed.

Jansen, K. (2006) 'Banana Wars and the Multiplicity of Conflicts in Commodity Chains', European Review of Latin American and Caribbean Studies, 81: 97-113.

Jansen, K. (2008) 'The Unspeakable Ban: The Translation of Global Pesticide Governance into Honduran National Regulation', World Development, 36(4): 575-589.

Jansen, K. (2017) 'Business Conflict and Risk Regulation: Understanding the Influence of the Pesticide Industry', Global Environmental Politics, 17(4): 48-66.

Jansen, K. and Dubois, M. (2014) 'Global Pesticide Governance by Disclosure: Prior Informed Consent and the Rotterdam Convention', in Gupta, A. and Mason, M. (eds) Transparency in Global Environmental Governance: Critical Perspectives, pp. 107-131. Cambridge, MIT Press.

Jansen, K. and Vellema, S. (2011) 'What is Technography?', NJAS Wageningen Journal of Life Sciences, 57(3-4): 169177.

Jas, N. (2007) 'Public Health and Pesticide Regulation in France Before and After Silent Spring', History and Technology, 23(4):369-388.

Karlsson, S. I. (200o) Multilayered Governance: Pesticides in the South, Environmental Concerns in a Globalised World: Linköping University, Dept. of Water Environmental Studies.

Marquardt, S. (2002) 'Pesticides, Parakeets, and Unions in the Costa Rican Banana Industry, 1938-1962', Latin American Research Review, 37(2): 3-36.

Murray, D. L. and Raynolds, L. T. (200o) 'Alternative trade in bananas: obstacles and opportunities for progressive social change in the global economy', Agriculture and Human Values, 17(1): 65-74.

Rajan, S. R. (2002) 'Missing Expertise, Categorical Politics, and Chronic Disasters - the Case of Bhopal', in Hoffman, S. and Oliver-Smith, A. (eds) Catastrophe and Culture: The Anthropology of Disaster, pp. 237-259. New Mexico, School of American Research (SAR).

Ramírez, F., Chaverri, F., de la Cruz, E., Wesseling, C., Castillo, L. and Bravo, V. (2009) Importación de plaguicidas en Costa Rica: periodo 1977-2006, Heredia, Costa Rica: Central American Institute for Studies in Toxic Substances - IRET. 
Ríos-González, A., Jansen, K. and Sánchez-Pérez, H. J. (2013) 'Pesticide Risk Perceptions and the Differences between Farmers and Extensionists: Towards a Knowledge-in-Context Model', Environmental Research, 124: 43-53.

Rosenthal, E. (2004) 'The DBCP Pesticide Cases: Seeking Access to Justice to Make Agribusiness Accountable in the Global Economy', in Jansen, K. and Vellema, S. (eds) Agribusiness and Society: Corporate Responses to Environmentalism, Market Opportunities and Public Regulation, pp. 176-199. London, Zed.

Rother, H.-A. (2008) 'South African Farm Workers' Interpretation of Risk Assessment Data Expressed as Pictograms on Pesticide Labels', Environmental Research, 108(3): 419-427.

Stadlinger, N., Mmochi, A. J., Dobo, S., Gyllbäck, E. and Kumblad, L. (2011) 'Pesticide Use Among Smallholder Rice Farmers in Tanzania', Environment, Development and Sustainability, 13(3): 641-656.

Thrupp, L. A. (1991) 'Sterilization of Workers from Pesticide Exposure: The Causes and Consequences of DBCPinduced Damage in Costa Rica and Beyond', International Journal of Health Services, 21(4): 731-757.

Toleubayev, K., Jansen, K. and Van Huis, A. (2007) 'Locust Control in Transition: The Loss and Reinvention of Collective Action in Post-Soviet Kazakhstan', Ecology and Society, 12(2): 38. [online] URL: http://www.ecologyandsociety.org/vol12/iss2/art38/.

Toleubayev, K., Jansen, K. and Van Huis, A. (2010a) 'Commodification of Science and the Production of Public Goods: Plant Protection Research in Kazakhstan', Research Policy, 39(3): 411-421.

Toleubayev, K., Jansen, K. and Van Huis, A. (2010b) 'Knowledge and Agrarian De-collectivisation in Kazakhstan', Journal of Peasant Studies, 37(2):353-377.

Toleubayev, K., Jansen, K. and Van Huis, A. (2011) 'From Integrated Pest Management to Indiscriminate Pesticide Use in Kazakhstan', Journal of Sustainable Agriculture, 35(4): 350-375.

van Wendel de Joode, B. and Barraza, D. (2007) 'An Ecosystem Approach to Pesticide Exposure and Children's Health in Communities Living in the Vicinity of Banana Plantations'. Heredia, Instituto Regional de Estudios en Sustancias Tóxicas, Universidad Nacional.

van Wendel de Joode, B., Barraza, D., Ruepert, C., Mora, A. M., Córdoba, L., Öberg, M., Wesseling, C., Mergler, D. and Lindh, C. H. (2012) 'Indigenous Children Living Nearby Plantations With Chlorpyrifos-treated Bags Have Elevated 3,5,6-trichloro-2-pyridinol (TCPy) Urinary Concentrations', Environmental Research.

van Wendel de Joode, B. N., Graaf, I. A. M. d., Wesseling, C. and Kromhout, H. (1996) 'Paraquat Exposure of Knapsack Spray Operators on Banana Plantations in Costa Rica', International Journal of Occupational and Environmental Health, 2(4): 294-304.

Vorley, W. (2004) 'Reconciling Shareholders, Stakeholders and Managers: Experiencing the Ciba-Geigy Vision for Sustainable Development', in Jansen, K. and Vellema, S. (eds) Agribusiness and Society: Corporate Responses to Environmentalism, Market Opportunities and Public Regulation, pp. 25-41. London, Zed.

Wesseling, C., Corriols, M. and Bravo, V. (2005) 'Acute Pesticide Poisoning and Pesticide Registration in Central America', Toxicology and Applied Pharmacology, 207(2, Supplement 1, 1): S697-S705.

Wesseling, C., Keifer, M., Ahlbom, A., McConnell, R., Moon, J.-D., Rosenstock, L. and Hogstedt, C. (2002) 'Longterm Neurobehavioral Effects of Mild Poisonings with Organophosphate and n-Methyl Carbamate Pesticides among Banana Workers', International Journal of Occupational and Environmental Health, 8(1): 27-34.

Wesseling, C., McConnell, R., Partanen, T. and Hogstedt, C. (1997) 'Agricultural Pesticide Use in Developing Countries: Health Effects and Research Needs', International Journal of Health Services, 27(2): 273-308.

Widgers, T. (2014) 'Pesticides and Global Health: 'Ambivalent Objects' in Anthropological Perspective', Somatosphere. http://somatosphere.net/?p=8770. 